\title{
Systemic and Pulmonary Vascular Effects of Selective Dopamine Receptor Blockade and Stimulation in Lambs
}

\author{
MARK J. POLAK AND WILLA H. DRUMMOND \\ Departments of Pediatrics, West I'irginia University School of Medicine, Morgantown. West I'irginia. 26506 \\ [M.J.P.J: and the University of Florida College of Medicine. Gainesville, Florida 32610 /W.H.D.]
}

\begin{abstract}
Vascular dopamine $\left(\mathrm{DA}_{1}\right)$ receptors may modulate circulatory hemodynamics in lambs. We evaluated resting dopaminergic tone in lambs by pharmacologically manipulating peripheral $\mathrm{DA}_{1}$ receptors with i.v. SCH 23390, (a highly selective, competitive $\mathrm{DA}_{1}$ receptor antagonist) and i.v. fenoldopam, (a highly selective $\mathrm{DA}_{1}$ receptor agonist) in unanesthetized lambs, instrumented for circulatory studies, while measuring the systemic and pulmonary vascular changes that the manipulations induced. We examined both the independent effects of $\mathrm{DA}_{1}$ receptor stimulation and blockade as well as the effects of the agonist and the antagonist infused together (competitive interaction). SCH 23390 , infused at $2.5 \mu \mathrm{g} / \mathrm{kg} \cdot \mathrm{min}^{-1}$, caused significant increases in left atrial, systemic, and pulmonary artery pressure, as well as an increase in systemic vascular resistance and a decrease in heart rate. Fenoldopam, infused at the dose of $60 \mu \mathrm{g} / \mathrm{kg} \cdot \mathrm{min}^{-1}$ caused significant decreases in mean systemic artery pressure and systemic vascular resistance while increasing cardiac index and mean pulmonary artery pressure. SCH 23390 blunted the fenoldopam-induced effects. Our data suggest that dopaminergic influence may be active in the maintenance of resting hemodynamics of the lamb. (Pediatr Res 33: 181-184, 1993)
\end{abstract}

\section{Abbreviations}

$\mathrm{DA}_{1}$, postsynaptic, vascular dopamine receptor

PAP, mean pulmonary artery pressure

LAP, mean left atrial pressure

SAP, mean systemic artery pressure

QP, pulmonary blood flow

SVR, systemic vascular resistance

PVR, pulmonary vascular resistance

A wide variety of responses are evoked by infused dopamine. This occurs because the hemodynamic effects of dopamine receptor stimulation are obscured by simultaneous stimulation of $\alpha$ and $\beta$-adrenergic receptors ( 1 ). Thus, the unique contribution of dopamine receptors to overall circulatory dynamics has been difficult to discern. The availability of selective dopamine receptor agonists and antagonists has greatly increased our understanding of the function of vascular dopamine receptors. Much of the research has dealt with manipulation of dopamine receptors in disease states $(2,3)$ or acute anesthetized $(4,5)$ or isolated organ

Received April 30, 1992; accepted September 25. 1992.

Correspondence and reprint requests: Mark J. Polak, M.D.. Department of Pediatrics. PO Box 9214, Health Science Center. North. West Virginia University School of Medicine. Morgantown. WV 26506. models (6), which does not address the role of dopaminergic function under normal physiologic states.

Dopamine concentrations in amniotic fluid and in plasma of fetuses are higher than plasma levels in adults $(7,8)$. These data provide some indirect evidence that endogenous dopamine is important in the fetus and newborn. Studies investigating dopamine receptor density and affinity in the fetal and newborn kidney, as well as studies examining the physiologic responses to dopaminergic stimulation in fetal and newborn animals, have not provided a concise answer, though they also point to a role of dopamine as a factor in fetal development (9-11). Most of this research has focused on renal tubular effects of dopamine. though vasodilating dopamine receptors are also present in mesenteric, coronary, and pulmonary vascular beds $(6,12,13)$ of adult animals. Weir (14) has postulated that in the pulmonary circulation, the normal. low vascular tone is the active phase of the vascular response. If the factors causing the vasodilation are removed, vasoconstriction results (14). It is possible that active vasodilation also occurs in the systemic circulation where, as suggested by Bell (15), endogenous dopamine has a physiologic function in control of blood volume and blood pressure. Defects in the dopaminergic system may play an important role in the etiology of hypertensive states (16). Vascular receptors mediating vasodilation, such as $\mathrm{DA}_{1}$, may play a significant role in the maintenance of the vascular hemodynamics, especially for the fetus and during the transitional circulation period of the newborn.

We hypothesized that if systemic and pulmonary $\mathrm{DA}_{1}$ receptors are chronically occupied by endogenous dopamine, the application of a receptor antagonist would "turn off" the active vasodilation and lead to observable hemodynamic alterations. We studied this hypothesis by selectively blocking peripheral

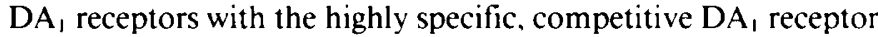
antagonist, $\mathrm{SCH} 23390$. We also infused the selective $\mathrm{DA}_{1}$ agonist, fenoldopam, alone and in combination with SCH 23390. These compounds were infused into healthy, unanesthetized lambs instrumented for circulatory studies. We report the effects of these vascular $\mathrm{DA}_{\text {, }}$ receptor manipulations.

\section{MATERIALS AND METHODS}

Twelve mixed-breed lambs, 1 to $3 \mathrm{~d}$ old, were instrumented in the following manner. Polyethylene catheters were placed in the inferior vena cava and descending aorta by cutdown of the hindlimb. Then, via a left lateral thoracotomy, an electromagnetic flow transducer was placed around the main pulmonary artery; catheters were placed into the main pulmonary artery (distal to the flow transducer) and into the left atrium, and the ductus arteriosus was ligated. The catheters and flow probe cable were exteriorized to a canvas pouch on the lamb's flank, and the lamb was allowed to recover from surgery for approximately 3 d. The experiments were conducted with lambs between 7 and 
$14 \mathrm{~d}$ of age. All experiments were performed while the lambs were suspended upright in a sling, spontaneously breathing room air. All procedures were performed in accordance with National Institutes of Health animal utilization policies. During the experiments, we measured systemic and pulmonary vascular pressures and left atrial pressures using Gould-Brush PB2310 transducers and a Gould 2800 physiologic recorder. We measured pulmonary blood flow using a Gould-Statham SP2202 flow meter interfaced to the physiologic recorder.

We measured mean PAP, SAP, LAP, QP, and heart rate in all lambs. Because the ductus arteriosus was ligated in all lambs, pulmonary blood flow equalled cardiac output. We calculated PVR; PVR = (PAP - LAP $) / Q P \cdot \mathrm{kg}^{-1}$. SVR was calculated using the formula $\mathrm{SVR}=\mathrm{SAP} / \mathrm{QP} \cdot \mathrm{kg}^{-1}$, assuming that right atrial pressure was negligible compared with systemic pressure.

SCH 23390 (Schering Corporation, Bloomfield, NJ), is a highly specific, competitive $\mathrm{DA}_{1}$ receptor antagonist (5, 17-19). Renal $\mathrm{DA}_{1}$ receptors in the dog have been completely blocked by a dose as low as $0.5 \mu \mathrm{g} / \mathrm{kg} \cdot \mathrm{min}^{-1}$, whereas $\mathrm{DA}_{1}$ selectivity is retained at doses up to $30 \mu \mathrm{g} / \mathrm{kg} \cdot \mathrm{min}^{-1}$. For this experiment, we chose to infuse the SCH 23390 at a dose of $2.5 \mu \mathrm{g} / \mathrm{kg} \cdot \mathrm{min}^{-1}$, which was derived from studies previously reported $(5,17-19)$ and pilot studies from our lab. SCH 23390 is considered to be the gold standard for both pharmacologic blockade of $\mathrm{DA}_{1}$ receptors and, in a tritiated form, for dopamine receptor identification (20), though experience with this compound in lambs is somewhat limited $(11,21)$.

Fenoldopam mesylate (SKF-82526; Smith, Kline, and Beecham Laboratories, Philadelphia, PA) is a benzapine compound developed as an antihypertensive agent. It is a selective $\mathrm{DA}_{1}$ agonist at doses from 0.1 to $100 \mu \mathrm{g} / \mathrm{kg} \cdot \mathrm{min}^{-1}(4,22)$. A dose of $60 \mu \mathrm{g} / \mathrm{kg} \cdot \mathrm{min}^{-1}$ was chosen based on data from our lab showing significant alterations in hemodynamic variables, presumably via stimulation of $\mathrm{DA}_{1}$ receptors (23).

For both drugs, physiologic saline was used as the vehicle. All drug infusions were into the inferior vena cava. The experimental protocols are outlined in Figure 1. On 2 separate d, each lamb received either an infusion of saline (control) and fenoldopam, or SCH 23390 and fenoldopam. As such, we were able to examine the independent effects of $\mathrm{DA}_{1}$ receptor stimulation and blockade as well as the effects of the agonist and the antagonist infused together.

Each study began with a 20 -min baseline period, during which time the lamb acclimated to the sling and laboratory environment. Baseline hemodynamic variables were recorded at the end of this period, and arterial blood was sampled for $\mathrm{pH}$, arterial $\mathrm{O}_{2}$ tension, and arterial $\mathrm{CO}_{2}$ tension. We then started an infusion of either SCH 23390 at $2.5 \mu \mathrm{g} / \mathrm{kg} \cdot \mathrm{min}^{-1}$ or an equivalent volume of physiologic saline. Changes in physiologic measurements were recorded, and an arterial blood gas was obtained $10 \mathrm{~min}$ from

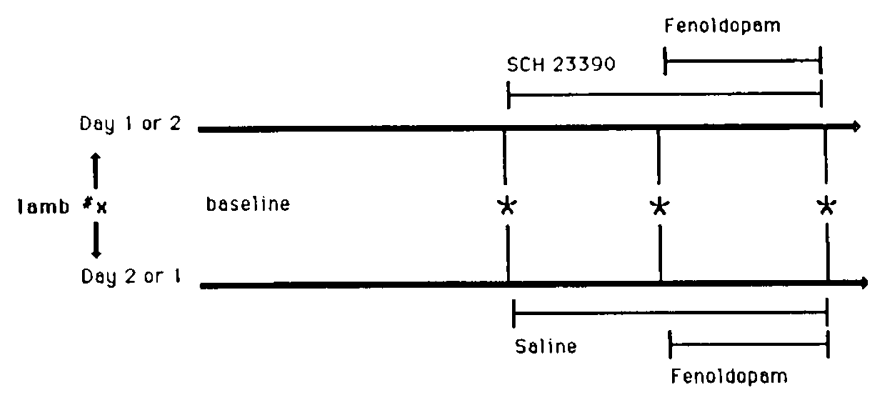

time $=\min$.

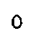

10

20

30

40

Fig. 1. Outline of experimental protocols. Each lamb was studied on 2 separate $d$. The order of studies was assigned randomly. *. Time period at which data (PAP. LAP. SAP. QP. heart rate. SVR, and PVR) were recorded and arterial blood was sampled for $\mathrm{pH}$. arterial $\mathrm{O}_{2}$ tension. and arterial $\mathrm{CO}_{2}$ tension. the start of the antagonist infusion. At this time, fenoldopam at $60 \mu \mathrm{g} / \mathrm{kg} \cdot \mathrm{min}^{-1}$ was infused into the lamb. Changes in physiologic measurements were recorded, and an arterial blood gas was obtained $10 \mathrm{~min}$ from the start of the agonist infusion.

The continuously measured physiologic variables (PAP, LAP, SAP, heart rate, $Q P / \mathrm{kg}$ ) and the calculated data (SVR, PVR) from baseline versus $\mathrm{DA}_{1}$ blockade with $\mathrm{SCH} 23390$ and from baseline versus $\mathrm{DA}_{1}$ stimulation with fenoldopam were compared and analyzed by a single-factor, repeated-measures analysis of variance. Changes in physiologic parameters as a result of simultaneous infusion of fenoldopam and SCH 23390 were recorded and compared with baseline, fenoldopam alone, and SCH 23390 alone. These data were analyzed by multifactor analysis of variance. All data are presented as mean \pm SD. The $\alpha$ level of significance was $p<0.05$.

\section{RESULTS}

For all experiments, the lambs maintained normal behavior and respiration $(60 \pm 15$ breaths/min). Arterial blood gas measurements also remained stable throughout all experiments: $\mathrm{pH}$ $7.38 \pm 0.04$, arterial $\mathrm{O}_{2}$ tension $81.0 \pm 10.0 \mathrm{~mm} \mathrm{Hg}(10.8 \pm 1.3$ $\mathrm{kPa})$, and arterial $\mathrm{CO}_{2}$ tension $36.0 \pm 5.0 \mathrm{~mm} \mathrm{Hg}(4.8 \pm 0.7$ $\mathrm{kPa})$. The systemic and pulmonary artery pressure and left atrial pressure are detailed in Figure 2. Heart rate, cardiac index, and stroke volume as well as pulmonary and systemic vascular resistance from the four groups are detailed in Table 1.

SCH 23390 infusion. Cardiac index was unaffected by $\mathrm{SCH}$ 23390 infusion. Heart rate decreased, whereas significant increases in stroke volume, systemic and pulmonary artery pressure, left atrial pressure, PVR, and SVR were noted.

Fenoldopam infusion. Fenoldopam, infused at the dose of 60 $\mu \mathrm{g} / \mathrm{kg} \cdot \mathrm{min}^{-1}$, caused significant decreases in systemic artery pressure and SVR while increasing cardiac index, heart rate, stroke volume, and pulmonary artery pressure. PVR was unaffected.

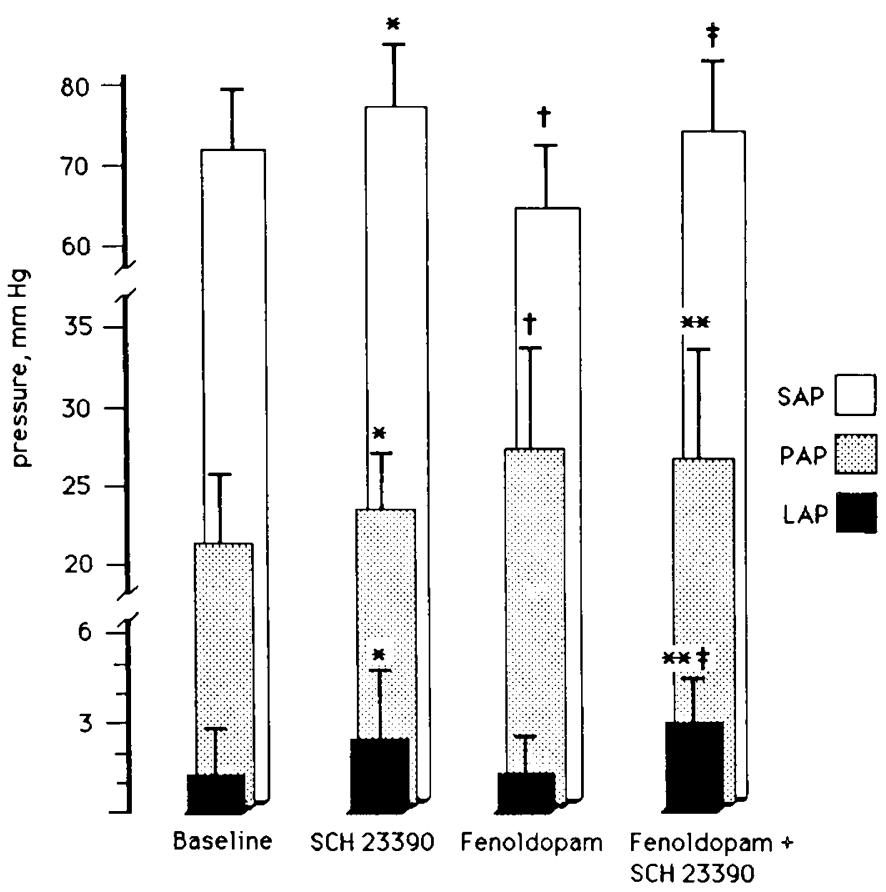

Fig. 2. Vascular pressure data recorded during baseline and the three experimental conditions. Baseline data from SCH 23390 experiments are presented. The baseline data from $\mathrm{d} 1$ and $\mathrm{d} 2$ experiments were similar. *, Significant difference of $\mathrm{DA}_{1}$ blockade (SCH 23390) $v$ s baseline by analysis of variance for repeated measures: $\downarrow$, significant difference of $\mathrm{DA}_{1}$ stimulation (fenoldopam) vs baseline by analysis of variance for repeated measures: ${ }^{* *}$, significant difference, baseline vs fenoldopam + $\mathrm{SCH}$ : and $\ddagger$, fenoldopam alone is fenoldopam $+\mathrm{SCH}$ by analysis of variance. The $\alpha$ level of significance is $p<0.05$. 
Table 1. Vascular effects of $D A_{1}$ hlockade (SCH 23390), DA, stimulation (fenoldopam), and combination (fenoldopam $+S C H$ 23390) in unanesthetized lamb*

\begin{tabular}{lcccc}
\hline & Baselinet & $\begin{array}{c}\mathrm{SCH} 23390 \\
\left(2.5 \mu \mathrm{g} / \mathrm{kg} \cdot \mathrm{min}^{-1}\right)\end{array}$ & $\begin{array}{c}\text { Fenoldopam } \\
\left(60 \mu \mathrm{g} / \mathrm{kg} \cdot \mathrm{min}^{-1}\right)\end{array}$ & $\begin{array}{c}\mathrm{SCH} 23390+ \\
\text { fenoldopam }\end{array}$ \\
\hline Heart rate $($ beats/min) & $208 \pm 27$ & $195 \pm 34 \ddagger$ & $230 \pm 30 \$$ & $198 \pm 40$ \\
Cardiac index $(\mathrm{QP} / \mathrm{kg})$ & $176.4 \pm 45.5$ & $176.8 \pm 41.1$ & $226.5 \pm 50.0 \S$ & $197.4 \pm 38.8$ \\
Stroke volume $(\mathrm{mL})$ & $3.8 \pm 1.0$ & $4.2 \pm 1.3 \ddagger$ & $4.4 \pm 1.3 \S$ & $4.3 \pm 0.7 \|$ \\
SVR [(PAP $-\mathrm{LAP}) / \mathrm{QP}] \cdot \mathrm{kg}^{-1}$ & $0.44 \pm 0.14$ & $0.50 \pm 0.13 \ddagger$ & $0.33 \pm 0.10 \$$ & $0.42 \pm 0.07$ \\
PVR [(SAP/QP) $\left.\mathrm{kg}^{-1}\right]$ & $0.12 \pm 0.04$ & $0.13 \pm 0.05 \ddagger$ & $0.12 \pm 0.03$ & $0.12 \pm 0.08$ \\
\hline
\end{tabular}

* Values are mean $\pm \mathrm{SD}$ for $n=12$.

† Baseline data from SCH 23390 experiments are presented. The baseline data from d I and d 2 experiments were similar.

$\ddagger$ Significant difference, $\mathrm{DA}_{1}$ blockade $v$ baseline by analysis of variance for repeated measures.

$\$$ Significant difference. $\mathrm{DA}_{1}$ stimulation $v$ s baseline by analysis of variance for repeated measures.

$\|$ Significant difference, baseline vs fenoldopam + SCH 23390 by analysis of variance. The $\alpha$ level of significance is $p<0.05$.

Finoldopam + SCH 23390. Simultaneous infusion of fenoldopam and SCH 23390 tended to attenuate the independent effects of both compounds. As a result of this competitive interaction, heart rate, systemic artery pressure, and SVR and PVR returned to baseline values. Values for cardiac index, stroke volume, pulmonary artery pressure, and left atrial pressure were between those of fenoldopam infused alone and SCH 23390 infused alone.

\section{DISCUSSION}

The chronically instrumented animal offers an excellent model for demonstration of pharmacologic manipulation of normal physiology. The setting is uncomplicated by the stress associated with general anesthesia and acute surgical intervention (24), and the lambs are trained to accept handling and are calm and unstressed during the experiments. Experimental results are therefore a reflection of a normal hemodynamic state with multisystem interactions that are impossible to reproduce with other experimental models.

The renal, mesenteric, coronary, and pulmonary vascular beds of mammals are populated with $\mathrm{DA}_{1}$ receptors $(6,12,13)$. Our data suggest that these receptors may be occupied chronically, providing a degree of vasodilation to maintain resting systemic and pulmonary pressure. As demonstrated from our data, blockade of these active, vasodilating receptors results in vasoconstriction with an elevation in systemic and pulmonary artery pressures, and SVR and PVR. This increase in SVR and subsequent increase in left ventricular afterload leads to an increase in left atrial pressure. A significant decrease in heart rate, which may be secondary to baroreflex mechanisms, was also noted.

Infusion of fenoldopam causes hemodynamic alterations that can, for the most part, be explained by $\mathrm{DA}_{1}$ receptor-induced vasodilation. Systemic arterial pressure and SVR drops. The significant increase in heart rate, cardiac index, and stroke volume with fenoldopam suggests that dopamine receptor stimulation exerts a chronotropic and ionotropic effect either directly or via secondary release of catecholamines. The increase in pulmonary artery pressure without a change in PVR is most likely the indirect result of increased QP and heart rate.

The effects of infusion of both agonist and antagonist represent a competitive receptor-ligand interaction. The wide range of hemodynamic responses, some attenuated toward baseline values, some closer to agonist responses, and some closer to antagonist-induced responses, suggest that perhaps $\mathrm{DA}_{1}$ receptors vary in affinity to SCH 23390 and/or fenoldopam. This possibility is consistent with recent studies demonstrating at least three different subtypes of the $\mathrm{DA}_{1}$ receptor (25).

Control of systemic and pulmonary vascular tone in the fetus and newborn is not dictated by any single mechanism. Research has indicated that fetal and newborn hemodynamics may be influenced by a variety of factors that are different from those in the adult (26-29). Some of the many factors involved in the control of systemic and pulmonary vascular dynamics include endothelial factors (endothelial-derived relaxing factor and endothelin), vasoactive compounds such as bradykinin and products of arachidonic acid metabolism, vasoactive peptides produced in the heart, and hypothalamus (vasopressin), and environmental factors (normoxia, hypoxia, $\mathrm{pH}$ ). All of these factors and mechanisms of action seem to interact in the normal maintenance of systemic and pulmonary vascular tone in both normal and abnormal conditions.

There is increasing evidence that the dopamine-dopaminergic receptor system also contributes to the active maintenance of fetal and newborn hemodynamics, which continues into adult life $(9-11,30)$. The most important role of dopamine in the fetus is control of renal function, primarily by affecting sodium excretion. These dopamine-receptor interactions are at the tubular level, with dopamine produced locally. The role of endogenous dopamine and vascular dopamine receptors in the fetus and newborn and their contribution to maintaining the hemodynamic state is not clear. Nakamura et al. (30) demonstrated an increase in renal blood flow with infused dopamine (with $\alpha$ - and $\beta$-adrenoreceptor blockade) in fetal, newborn, and adult sheep. though this effect has not been seen in all species $(31,32)$. Results from these studies do not directly correlate to normal physiology. Though plasma dopamine concentrations in the fetus and newborn are increased compared with adult levels $(7,8)$, they are certainly lower than levels achieved with these pharmacologic studies of dopamine. A dopaminergic role in systemic and/or pulmonary hemodynamics must therefore rely upon release of endogenous dopamine from adrenergic/dopaminergic nerve endings or direct tissue production.

We chose to approach the question of vascular dopaminergic function in newborns by examining both the $\mathrm{DA}_{1}$ antagonist, SCH 23390, and the selective $\mathrm{DA}_{1}$ agonist, fenoldopam, in a chronically instrumented, unanesthetized lamb model. This agonist-antagonist pair provides a powerful tool for delineating functional activity of dopamine receptors $(6,33)$. Our data show a clear pharmacologic importance of vascular dopamine receptors in modulation of systemic and pulmonary hemodynamics in the newborn. Other research has also demonstrated similar results. From preliminary data, Segar et al. (11) have noted changes in hemodynamic variables with infusion of SCH 23390 into chronically instrumented fetal sheep. We have also reported preliminary data demonstrating an increase in pulmonary dopaminergic activity within the $1 \mathrm{wk}$ of life of the rabbit, suggesting a dopaminergic role in the transitional circulation (34).

Besides the pharmacologic importance, our data from $\mathrm{DA}_{1}$ blockade studies suggest a physiologic importance for vascular dopamine receptors. Infusion of SCH 23390 alters systemic and pulmonary hemodynamic variables. These effects may be due to a "turning off" of active vascular vasodilating dopamine receptors. These data, as well as evidence from other studies $(9,11$, $15,30,34)$, suggest that endogenous dopamine and dopamine receptors are active in maintenance of normal hemodynamics in the newborn. 
Acknowledgments. SCH 23390 was provided by Schering Corporation, Bloomfield, NJ. Fenoldopam was provided by Smith, Kline, and Beecham Laboratories, Philadelphia, PA.

\section{REFERENCES}

1. Goldberg LI 1972 Cardiovascular and renal actions of dopamine: potential clinical applications. Pharmacol Rev 24:1-29

2. Caruana MP, Heber M. Brigden G. Raftery EB 1987 Effects of fenoldopam. a specific dopamine receptor agonist, on blood pressure and left ventricular function in systemic hypertension. Br J Clin Pharmacol 24:721-727

3. Young JB, Leon CA, Pratt CM. Kingry C, Taylor AA, Roberts R 1988 Intravenous fenoldopam in heart failure: comparing the hemodynamic effects of dopamine, receptor agonism with nitroprusside. Am Heart $\mathrm{J}$ 115:378-384

4. Lokhandwala MF, Watkins HO, Sabouni MH, Alkadhi KA 1985 Pharmacological analysis of the actions of SKF 82526 on cardiovascular dopamine receptors. J Pharmacol Exp Ther 234:337-344

5. Fredrickson ED. Bradley T, Goldberg LI 1985 Blockade of renal effects of dopamine in the dog by the DAl antagonist SCH 23390. Am J Physiol 249:F236-F240

6. Polak MJ, Knight ME, Gause GE, Bucciarelli RL, Drummond W 1989 Effect of fenoldopam on preconstricted isolated salt-perfused rat lungs. J Appl Physiol 67:1076-1080

7. Phillipe M, Ryan KJ 1981 Catecholamines in human amniotic fluid. Am J Obstet Gynecol 139:204-208

8. Eliot RJ. Klein AH, Glatz TH, Nathanielsz PW, Fisher DA 1981 Plasma norepinephrine, epinephrine, and dopamine concentrations in maternal and fetal sheep during spontaneous parturition and in premature sheep during cortisol induced parturition. Endocrinology 108:1678-1682

9. Seri I 1990 Dopamine and natriuresis. Mechanism of action and developmental aspects. Am J Hypertens 6:82S-86S

10. Robillard JE, Segar JL, Smith FG, Jose PA 1992 Regulation of sodium metabolism and extracellular fluid volume during development. Clin Perinatol 19:15-31

11. Segar JL, Smith BA. Smith FG, Jose PA, Robillard JE 1991 Role of endogenous dopamine (DA) and dopamine $1\left(\mathrm{DA}_{1}\right)$ receptors in the control of arterial pressure and renal function during fetal life. Pediatr Res 29:65A (abstr)

12. Missale C. Pizzi M, Memo M. Picotti GB, Carruba MO, Spano PF 1985 Post synaptic D1 and D2 dopamine receptors are present in rabbit renal and mesenteric arteries. Neurosci Lett 61:207-211

13. Sandrini M, Benelli A, Baraldi M 1984 Dopamine receptors in the guinea-pig heart: a binding study. Life Sci 35:1839-1849

14. Weir EK 1978 Does normoxic pulmonary vasodilation rather than hypoxic vasoconstriction account for the pulmonary pressor response to hypoxia? Lancet 1:476-478

15. Bell C 1987 Endogenous renal dopamine and control of blood pressure. Clin Exper Theory Pract A9:955-975
16. Goldberg LI 1984 Dopamine and hypertension: phvsiological and pharmacological implications. Am J Med 77:37-44

17. Goldberg LI. Glock D. Kohli JD 1984 Separation of peripheral dopamine receptors by a selective DAI antagonist. SCH 23390. Hypertension 6(suppl 1): $125-130$

18. Hildritch A. Drew GM. Naylor RJ 1984 SCH 23390 is a very potent and selective antagonist at vascular dopamine receptors. Eur $\mathrm{J}$ Pharmacol 97:333-334

19. Iorio LC. Barnett A, Leitz FH. Houser VP, Korduba CA 1983 SCH 23390. a potential benzapine antipsychotic with unique interactions on dopaminergic systems. J Pharmacol Exp Ther 226:462-468

20. Andersen PH. Grønvald FC 1986 Specific binding of ${ }^{3} \mathrm{H}-\mathrm{SCH} 23390$ to dopamine D1 receptors in vivo. Life Sci 38:1507-1514

21. Felder RA, Nakamura KT, Robillard JE, Kanadjian M, Jose PA 1988 Dopamine receptors in the developing sheep kidney. Pediatr Nephrol 2:156-162

22. Shebuski RJ. Smith LM, Ruffolo RR 1988 Comparison of the renal and pulmonary hemodynamic effects of fenoldopam, dobutamine, dopamine. and norepinephrine in the anesthetized dog. Pharmacology 36:35-43

23. Drummond WH, Williams BJ, Kelley KC 1983 Pulmonary and systemic vascular effects of SKF-82526-J, a new specific peripheral dopamine receptor agonist in unanesthetized neonatal lambs. Dev Pharmacol Ther 6:1-8

24. Walker LA, Buscemi-Bergin M. Gellai M 1983 Renal hemodynamics in conscious rats; effects of anesthesia, surgery, and recovery. Am J Physiol 245:F67-F74

25. Gingrich JA, Jarvie K. Tiberi M, Fremeau RT, Caron MG 1992 The family of receptors for dopamine: cloning, structures, and properties. Biotech Update $7: 105-112$

26. Pearce WJ, Longo LD 1991 Developmental aspects of endothelial function. Semin Perinatol 15:40-48

27. Fineman JR, Soifer SJ, Heymann MA 1991 The role of pulmonary vascular endothelium in perinatal pulmonary circulatory regulation. Semin Perinatol $15: 58-62$

28. Smith FG, Sato T, Varille VA, Robillard JE 1990 Atrial natriuretic factor during fetal and postnatal life: a review. J Dev Pharmacol 12:55-62

29. Robillard JE, Weitzman RE 1980 Developmental aspects of the fetal renal response to exogenous arginine vasopressin. Am J Physiol 238:F407-F414

30. Nakamura KT. Felder RA, Jose PA, Robillard JE 1987 Effects of dopamine in the renal vascular bed of fetal, newborn, and adult sheep. Am J Physiol 252:R490-R497

31. Driscoll DJ, Gillette PC, Lewis RM, Hartley CJ. Schwartz A 1979 Comparative hemodynamic effects of isoproterenol, dopamine. and dobutamine in the newborn dog. Pediatr Res 13:1006-1009

32. Buckley NM, Brazeau MP, Frasier ID 1983 Cardiovascular effects of dopamine in developing swine. Biol Neonate 43:50-60

33. Polak MJ, Kennedy LA. Drummond WH 1992 Manipulation of dopamine receptors alters hypoxic pulmonary vasoconstriction in isolated perfused rat lungs. Life Sci 51:1317-1323

34. Polak MJ. Taylor DA 1992 Ontogenv of pulmonary vascular dopamine receptors in preconstricted isolated perfused rabbit lungs. Pediatr Res 31:64A (abstr) 